\title{
Expression of autophagy genes in acute myeloid leukemia: associations with clinical characteristics and prognosis
}

\author{
P. Q. LIANG, M. MIAO, Z. G. LIU*, R. HU*, H. N. JIANG, C. LI, S. Y. MA \\ Hematology Department, Shengjing Hospital, China Medical University, Shenyang, Liaoning Province, China \\ *Correspondence: liuzg@sj-hosptial.org; hur@sj-hospital.org
}

Received October 28, 2017 / Accepted February 1, 2018

\begin{abstract}
The relationships between autophagy-associated gene expression, clinical characteristics and prognosis in acute myeloid leukemia (AML) have not been elucidated. Herein, we collected AML patient clinical information, treatment responses and outcomes and assessed the mRNA expression of Bcl-2, p62, Beclin 1, VPS34, Rubicon, ALFY, UVRAG, ULK1, LC3 and NBR1 in 20 AML patients and 10 benign hematological cases by real-time PCR. We determined that Beclin 1, LC3, UVRAG, Rubicon and NBR1 are down-regulated in AML patients compared to the control group ( $\mathrm{p}<0.05)$ and that low ULK1 expression was associated with high white blood cell counts $(\mathrm{p}<0.05)$. Autophagy-associated gene expression did not correlate with chemotherapy response. Although analysis of patient overall survival established no obvious association with gene expression, low Beclin 1 and p62 expression in unfavorable outcome patients was associated with worse overall survival than high-expression. The combined results confirm that autophagy genes are associated with outcome in AML patients and that they are potential biomarkers and targets in acute myeloid leukemia.
\end{abstract}

Key words: acute myeloid leukemia, autophagy, clinical outcome

Acute myeloid leukemia (AML) is a hematological malignancy with high morbidity and great heterogeneity, and the curative effect of standard AML therapies and its prognosis remain poor. One of the aims of AML research is to find new biomarkers that predict therapeutic response and prognosis. Autophagy is a self-protective process activated by hunger, hypoxia, drug stimulation and other aberrant conditions, and it can regulate cell fate by both promoting and inhibiting apoptosis [1]. Furthermore, autophagy has been shown to play important roles in the pathogenesis, differentiation, relapse and drug resistance of AML $[2,3]$.

The expression of autophagy-associated genes is thought to be associated with clinical outcomes in other malignancies, including colorectal, breast and prostate cancers [4-6]. Previous studies reported that Bcl-2-interacting myosin-like coiled-coil protein (Beclin 1) and microtubule associated protein 1 light chain 3 alpha (LC3) were downregulated in AML $[7,8]$. Activation and regulation of autophagy cells form a complicated network, and herein, we examined the mRNA expression levels of the following 10 autophagy regulators in AML patients: Beclin 1, LC3, B-cell lymphoma 2 (Bcl-2), p62, vacuolar protein sorting 34 (VPS34), RUN and cysteine rich domain containing Beclin 1 interacting protein (Rubicon), autophagy-linked FYVE protein (ALFY), ultraviolet irradiation resistance-associated gene (UVRAG), UNC-51-like kinase 1 (ULK1), and 'Next to BRCA1 gene 1' (NBR1). We determined the expression level of autophagyassociated factors, revealed the relationships between autophagy and AML in clinical cases and identified the need to find new indicators for AML diagnosis and treatment.

\section{Patients and methods}

Patients. Bone marrow samples were collected from 20 newly-diagnosed AML patients (M3 type excluded) in our center between June 2015 and January 2017. All patients were diagnosed according to the WHO 2008 criteria for AML [9]. We also recruited 10 patients with benign hematological diseases such as anemia and thrombocytosis as the control group. We used only residual bone marrow samples remaining after necessary laboratory examinations, informed consent was obtained from all patients prior to their inclusion and the study was approved by the Ethics Committee in accordance with the Declaration of Helsinki. The following clinical information was collected; age, gender, bone marrow and routine blood results, fusion genes, karyotypes, mutant genes, chemotherapy response and survival time. Patients received induction chemotherapy regimens with dauno- 
Table 1. Primers used in this study.

\begin{tabular}{|c|c|c|c|}
\hline Name & Gene ID & Forward (5'-3') & Reverse (5'-3') \\
\hline Bcl-2 & 596 & TGGGATGCCTTTGTGGAACT & GAGACAGCCAGGAGAAATCAA \\
\hline p62 & 8878 & CGTCTGCCCAGACTAACT & GTGTCCGTGTTTCACCTTCC \\
\hline Beclin 1 & 8678 & TGAGGGATGGAAGGGTCTAA & CCTGGGCTGTGGTAAGTAATG \\
\hline VPS34 & 5289 & ATCCCGTTGCCTTTAGAACC & TGCCTCCATCTTCCGTCTTA \\
\hline Rubicon & 9711 & GTGATTCGGCACAGCTCTCT & ACTGGGAGGAAACGAAGGAT \\
\hline ALFY & 23001 & GGTCAGTGACACAGCCAGA & GCATGAAGACCAGCTTCAC \\
\hline UVRAG & 7405 & CTGGGAGAATTTGAAGAGTTC & GTCCTACTGTTGACCTGCTC \\
\hline ULK1 & 8408 & TCGAGTTCTCCCGCAAGG & CGTCTGAGACTTGGCGAGGT \\
\hline LC3 & 84557 & CTGTTGGTGAACGGACACAG & ACAATTTCATCCCGAACGTCT \\
\hline NBR1 & 4077 & GACATTTGCCTTGCCTGAAG & ТССТССТССТССТСАТССТС \\
\hline GAPDH & 2597 & TCCACTGGCGTCTTCACC & GGCAGAGATGATGACCCTTTT \\
\hline
\end{tabular}

Table 2. Cytogenetic/molecular genetic risk stratification.

\begin{tabular}{lll}
\hline & Cytogenetics & Molecular Genetics \\
\hline Favorable & inv $(16)(\mathrm{p} 13 \mathrm{q} 22)$ or $\mathrm{t}(16 ; 16)(\mathrm{p} 13 ; \mathrm{q} 22)$ & NPM1 mutation without FLT3-ITD \\
& $\mathrm{t}(8 ; 21)(\mathrm{q} 22 ; \mathrm{q} 22)$ & Biallelic mutated CEBPA \\
Medium & normal karyotype & inv $(16)(\mathrm{p} 13 \mathrm{q} 22)$ or $(\mathrm{t} 16 ; 16)(\mathrm{p} 13 ; \mathrm{q} 22)$ with C-Kit mutation \\
& $\mathrm{t}(9 ; 11)(\mathrm{p} 22 ; \mathrm{q} 23)$ & $\mathrm{t}(8 ; 21)(\mathrm{q} 22 ; \mathrm{q} 22)$ with C-Kit mutation \\
Unfavorable & others & \\
& Monosomal karyotype & TP53 mutation \\
& complex karyotype $(\geq 3$ types $)$, without $\mathrm{t}(8 ; 21)(\mathrm{q} 22 ; \mathrm{q} 22)$, inv $(16)$ & RUNX1 (AML1) mutation \\
& $(\mathrm{p} 13 \mathrm{q} 22)$ or $\mathrm{t}(16 ; 16)(\mathrm{p} 13 ; \mathrm{q} 22)$ or $\mathrm{t}(15 ; 17)(\mathrm{q} 22 ; \mathrm{q} 12)$ & ASXL1 mutation \\
& -5 & FLT3-ITD mutation \\
& -7 & \\
& $5 \mathrm{q}-$ & \\
-17 or abn $(17 \mathrm{p})$ & \\
& $11 \mathrm{q} 23$ chromosome translocation, except $\mathrm{t}(9 ; 11)$ & \\
& inv $(3)(\mathrm{q} 21 \mathrm{q} 26.2)$ or $\mathrm{t}(3 ; 3)(\mathrm{q} 21 ; \mathrm{q} 26.2)$ & \\
$\mathrm{t}(6 ; 9)(\mathrm{p} 23 ; \mathrm{q} 34)$ & \\
$\mathrm{t}(9 ; 22)(\mathrm{q} 34.1 ; \mathrm{q} 11.2)$ & \\
\hline
\end{tabular}

rubicin and cytarabine or idarubicin and cytarabine. After initial induction treatment, we evaluated the curative effects as complete remission (CR) and non-remission (NR). and progression-free survival (PFS) was defined as the date from $\mathrm{CR}$ achievement to any disease relapse. Overall survival (OS) was counted from diagnosis to decease.

Real-time PCR gene expression analysis. Bone marrow mononuclear cells were isolated using Ficoll density gradient separation. Total RNA was extracted from $1 \times 10^{6}$ bone marrow mononuclear cells with TRIzol (Ambion, Waltham, MA, USA) using standard protocols. The mRNA expression levels of relevant genes were measured by LightCycler ${ }^{\circledast} 480$ Real-Time PCR System (Roche, Basel, Switzerland). The details were as follows: 95 C, 30s, 1 cycle; 95 C, 5 s and 60 C, 20s 40 cycles. The primers used for real-time PCR are shown in Table 1 . The $2^{-\Delta \Delta \mathrm{CT}}$ method calculated mRNA expression levels with the $2^{-\Delta \Delta C T}$ median values as the boundary between patients in the high-expression (gene-high) and low-expression (gene-low) groups.
Statistical analysis. All analyses were performed with SPSS version 19.0 (SPSS Inc., Chicago, IL, USA). Student's $t$ test detected differences in measurement data and Fisher's exact test counted data. The significance of associations was determined by Spearman's correlation test and overall survival rates (OS) were calculated by Kaplan-Meier curves. Cox regression then performed OS multivariate analysis. p-values less than 0.05 achieved statistical significance and $<0.01$ was considered highly significant.

Ethics committee approval. The study was conducted in accordance with the Declaration of Helsinki and was approved by the Ethics Committee (No. 2015PS120K).

\section{Results}

Expression levels of autophagy-associated genes in AML patients. We first analyzed the expression levels of autophagy-associated genes, and results confirmed that Beclin 1, LC3, UVRAG, Rubicon and NBR1 were 
down-regulated in AML patients compared to the control group $(\mathrm{p}<0.05$, Figure 1$)$. We then considered cytogenetic/molecular genetic risk stratification, with patients grouped as favorable, medium and unfavorable according to the Chinese guide for AML (Table 2) [10]. There were 7 and 13 patients in the favorable and unfavorable groups, respectively. While we found no difference in autophagy-associated gene expression between the favorable and control groups, Beclin1, LC3, VPS34, Rubicon, ALFY and NBR1 were down-regulated in the unfavorable group compared with controls, and VPS34 had higher expression in the favorable group than in the unfavorable group $(1.36 \pm 1.11$ vs $0.54 \pm 0.49, \mathrm{p}=0.032$, Figure 2 ). The relative mRNA expression levels in descending order were: Bcl-2, ULK1, p62, ALFY, VPS34, UVRAG, NBR1, Rubicon, Beclin 1 and LC3. We found that most autophagy-associated genes correlated with each other, and all correlations were positive. Table 3 shows that p62 positively correlated with all genes except Bcl-2 and that Beclin 1 positively correlated with all genes except Bcl-2 and NBR1.

Expression levels of autophagyassociated genes and baseline characteristics of AML patients. The AML patient baseline characteristics in Table 4 show that patient age ranged from 16 to 67 years old with 54.5 median, and no differences were found between autophagyassociated gene expression and age. There were 7 male and 13 female patients, and high Bcl-2 expression was more common in the males (76.92\% vs $14.29 \%, p=0.017)$. In addition, the low ULK1 expression group had higher white blood cell counts (WBC) than the high ULK1 expression group $(92.72 \pm 98.14$ vs $17.60 \pm 28.24, p=0.041)$. We analyzed the correlation of immunophenotype and autophagy-associated gene expression with Spearman analysis, and here CD34 and CD64 showed some correlation with the investi-
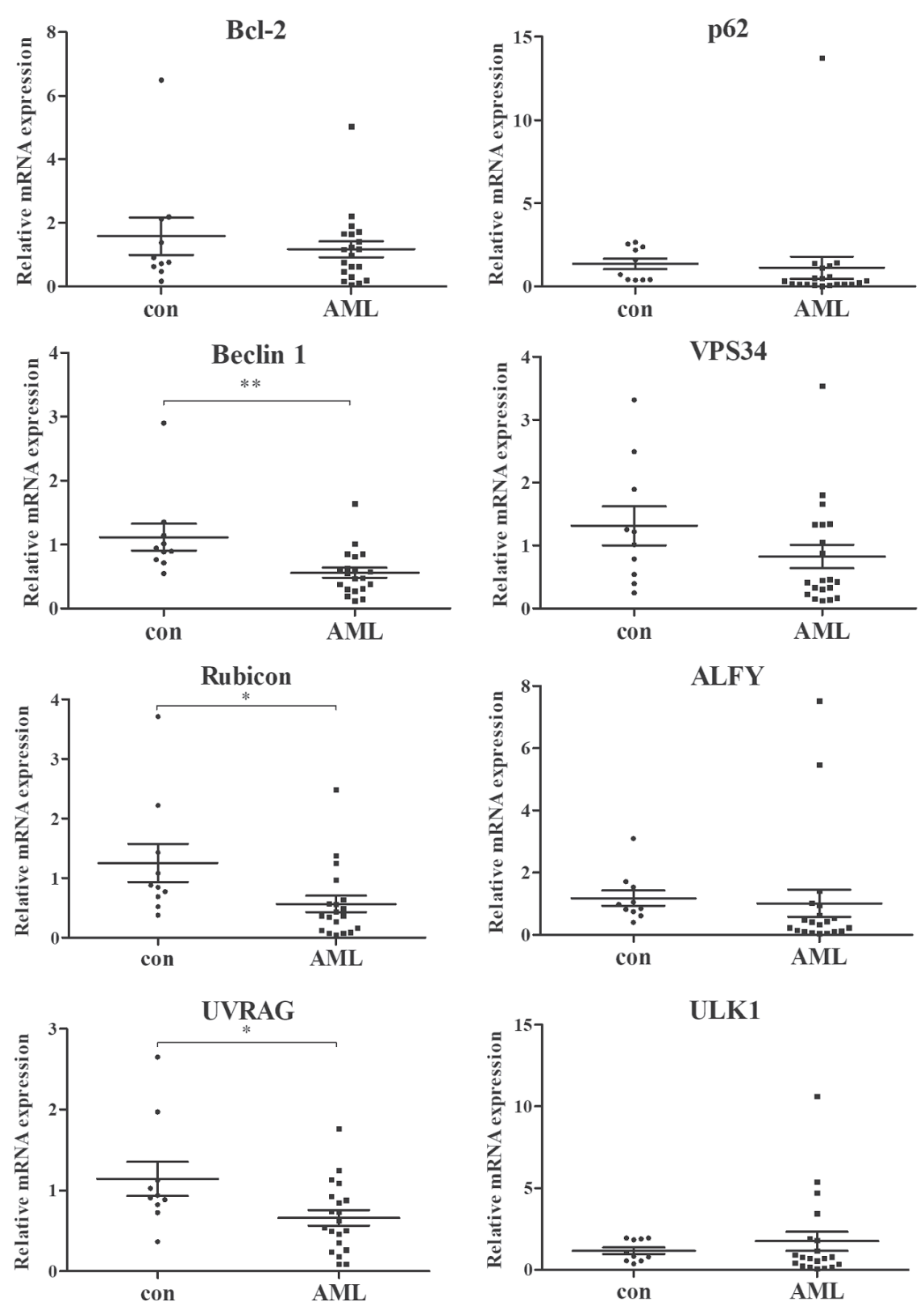

ULK1
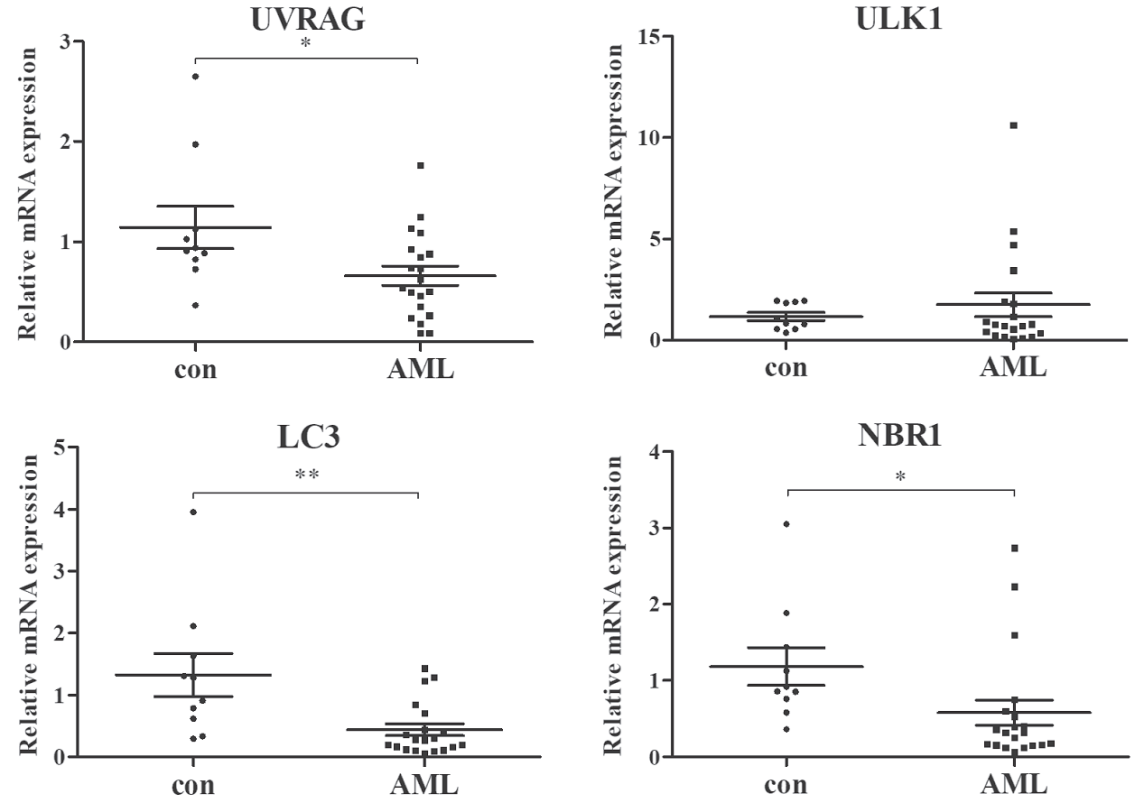

Figure 1. Gene expression in AML patients and control group. The expression levels of Beclin 1, LC3, UVRAG, Rubicon and NBR1 were all lower in AML patients than in the control group $(p<0.05)$. The $2^{-\triangle \triangle C T}$ method was used to calculate mRNA expression levels. “*” represent $p<0.05$ and “**" represent $\mathrm{p}<0.01$. 
Table 3. Correlations between autophagy-associated genes.

\begin{tabular}{|c|c|c|c|c|c|c|c|c|c|c|c|}
\hline & & Bcl-2 & p62 & Beclin1 & VPS34 & Rubicon & ALFY & UVRAG & ULK1 & LC3 & NBR1 \\
\hline \multirow[t]{2}{*}{ Bcl-2 } & $\mathrm{r}$ & 10.000 & 0.108 & 0.299 & 0.307 & $0.669^{* *}$ & 0.039 & 0.122 & 0.352 & -0.352 & $0.447^{*}$ \\
\hline & p-value & - & 0.650 & 0.200 & 0.188 & 0.001 & 0.870 & 0.609 & 0.128 & 0.128 & 0.048 \\
\hline \multirow[t]{2}{*}{ p62 } & $\mathrm{r}$ & 0.108 & 10.000 & $0.690^{* *}$ & $0.705^{* *}$ & $0.525^{*}$ & $0.492^{*}$ & $0.520^{*}$ & $0.743^{* *}$ & $0.603^{* *}$ & $0.493^{*}$ \\
\hline & p-value & 0.650 & - & 0.001 & 0.001 & 0.018 & 0.028 & 0.019 & 0.000 & 0.005 & 0.027 \\
\hline \multirow[t]{2}{*}{ Beclin1 } & $\mathrm{r}$ & 0.299 & $0.690^{* *}$ & 10.000 & $0.692^{* *}$ & $0.624^{* *}$ & $0.528^{*}$ & $0.600^{* *}$ & $0.814^{* *}$ & $0.543^{*}$ & 0.398 \\
\hline & p-value & 0.200 & 0.001 & - & 0.001 & 0.003 & 0.017 & 0.005 & 0.000 & 0.013 & 0.082 \\
\hline \multirow[t]{2}{*}{ VPS34 } & $\mathrm{r}$ & 0.307 & $0.705^{* *}$ & $0.692^{* *}$ & 10.000 & $0.547^{*}$ & 0.417 & 0.406 & $0.803^{* *}$ & 0.359 & 0.432 \\
\hline & p-value & 0.188 & 0.001 & 0.001 & - & 0.012 & 0.068 & 0.077 & 0.000 & 0.120 & 0.057 \\
\hline \multirow[t]{2}{*}{ Rubicon } & $\mathrm{r}$ & $0.669^{* *}$ & $0.525^{*}$ & $0.624^{* *}$ & $0.547^{*}$ & 10.000 & 0.412 & 0.394 & $0.723^{* *}$ & 0.089 & $0.615^{* *}$ \\
\hline & p-value & 0.001 & 0.018 & 0.003 & 0.012 & - & 0.071 & 0.086 & 0.000 & 0.710 & 0.004 \\
\hline \multirow[t]{2}{*}{ ALFY } & $\mathrm{r}$ & 0.039 & $0.492^{*}$ & $0.528^{*}$ & 0.417 & 0.412 & 10.000 & $0.535^{*}$ & $0.471^{*}$ & $0.783^{* *}$ & $0.621^{* *}$ \\
\hline & p-value & 0.870 & 0.028 & 0.017 & 0.068 & 0.071 & - & 0.015 & 0.036 & 0.000 & 0.003 \\
\hline \multirow[t]{2}{*}{ UVRAG } & $\mathrm{r}$ & 0.122 & $0.520^{*}$ & $0.600^{* *}$ & 0.406 & 0.394 & $0.535^{*}$ & 10.000 & 0.412 & $0.570^{* *}$ & 0.217 \\
\hline & p-value & 0.609 & 0.019 & 0.005 & 0.077 & 0.086 & 0.015 & - & 0.071 & 0.009 & 0.359 \\
\hline \multirow[t]{2}{*}{ ULK1 } & $\mathrm{r}$ & 0.352 & $0.743^{* *}$ & $0.814^{* *}$ & $0.803^{* *}$ & $0.723^{* *}$ & $0.471^{*}$ & 0.412 & 10.000 & 0.365 & $0.465^{*}$ \\
\hline & p-value & 0.128 & 0.000 & 0.000 & 0.000 & 0.000 & 0.036 & 0.071 & - & 0.113 & 0.039 \\
\hline \multirow[t]{2}{*}{ LC3 } & $\mathrm{r}$ & -0.352 & $0.603^{* *}$ & $0.543^{*}$ & 0.359 & 0.089 & $0.783^{* *}$ & $0.570^{* *}$ & 0.365 & 10.000 & 0.305 \\
\hline & p-value & 0.128 & 0.005 & 0.013 & 0.120 & 0.710 & 0.000 & 0.009 & 0.113 & - & 0.191 \\
\hline \multirow[t]{2}{*}{ NBR1 } & $\mathrm{r}$ & $0.447^{*}$ & $0.493^{*}$ & 0.398 & 0.432 & $0.615^{* *}$ & $0.621^{* *}$ & 0.217 & $0.465^{*}$ & 0.305 & 10.000 \\
\hline & p-value & 0.048 & 0.027 & 0.082 & 0.057 & 0.004 & 0.003 & 0.359 & 0.039 & 0.191 & - \\
\hline
\end{tabular}

${ }^{*}$ represents $\mathrm{p}<0.05,{ }^{* *}$ represents $\mathrm{p}<0.01$.

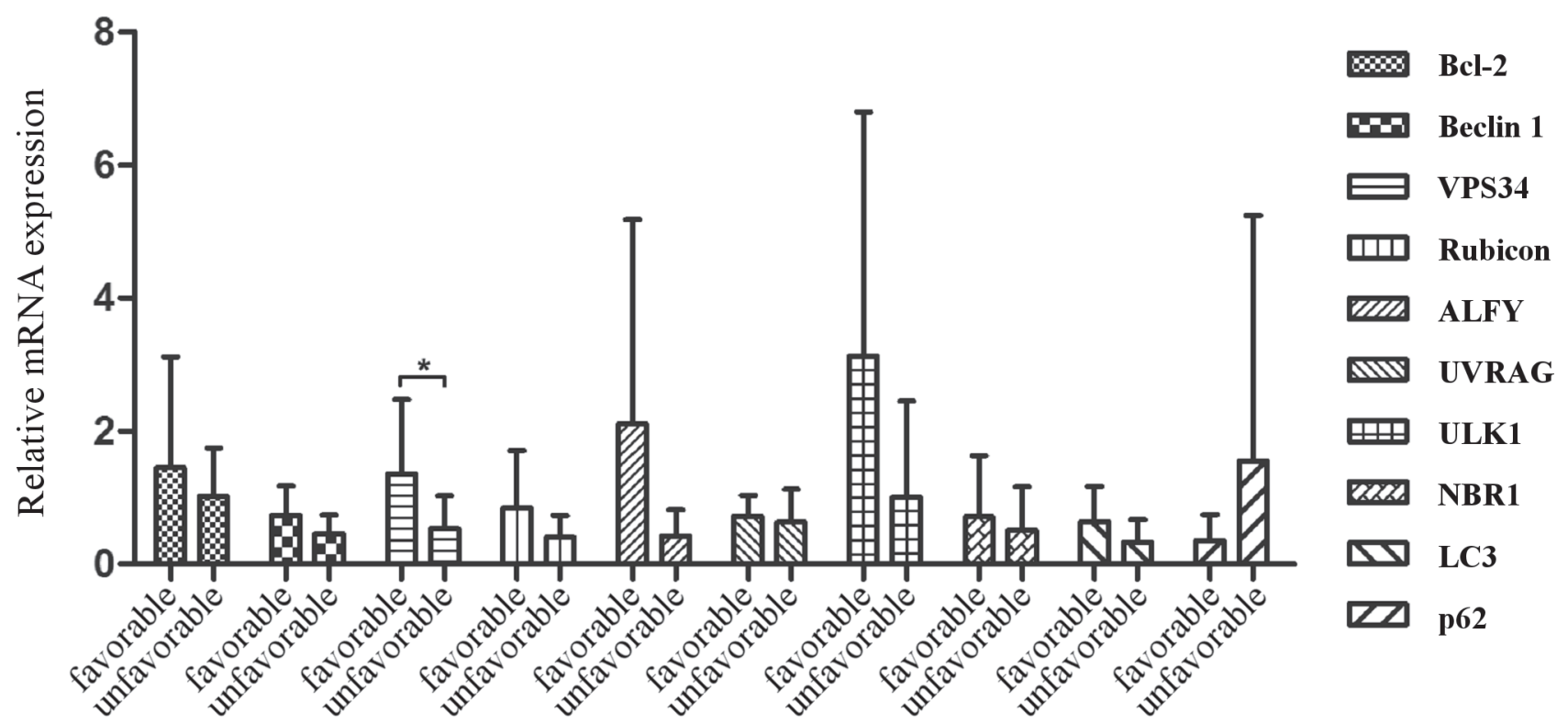

Figure 2. The expression level of VPS34 was higher in the favorable group $(\mathrm{p}<0.05)$. The $2^{-\Delta \Delta C T}$ method was used to calculate mRNA expression levels. “» represent $\mathrm{p}<0.05$. 
gated genes. Patients with lower Beclin 1, Rubicon and ULK1 expression had higher CD64 positive rates ( $80 \%$ vs $20 \%$, $\mathrm{p}=0.023$ ) and the high ALFY expression group had a higher CD34 positive rate than the low ALFY expression group ( $90 \%$ vs $30 \%, \mathrm{p}=0.02$ ). These results are shown in Table 5.

Effect of autophagy-associated gene expression on treatment response and prognosis. After induction chemotherapy, 9 patients achieved complete remission and 11 patients had non-remission. Analysis of the relationship between gene expression and chemotherapy response showed that those genes had no impact on treatment responses; with median OS time of 7.5 months. In addition, no genes had effect on PFS or OS. We then analyzed the relationship between gene expression and OS in the unfavorable group and patients with low Beclin 1 or p62 expression had worse OS than high-expression patients $(\mathrm{p}=0.029$ and $\mathrm{p}=0.006$, respectively). Moreover, multivariate analysis confirmed that neither Beclin 1 nor p62 made any contribution to OS. The survival curves of the unfavorable group are illustrated in Figure 3.

\section{Discussion}

Herein, we showed that many autophagy-associated genes were down-regulated in AML patients and that their downregulation was associated with clinical characteristics and
Table 4. Baseline characteristics of acute myeloid leukemia patients.

\begin{tabular}{|c|c|}
\hline \multicolumn{2}{|c|}{ Clinical characteristics of AML patients } \\
\hline Age & $16-67$ \\
\hline Gender (male:female) & $7: 13$ \\
\hline \multicolumn{2}{|l|}{ FAB classification } \\
\hline M0 & 1 \\
\hline M1 & 1 \\
\hline M2 & 6 \\
\hline M4 & 4 \\
\hline M5 & 7 \\
\hline M6 & 1 \\
\hline $\mathrm{WBC}\left(10^{9} / \mathrm{L}\right)$ & $55.16 \pm 80.15$ \\
\hline Neutrophils $\left(10^{9} / \mathrm{L}\right)$ & $7.05 \pm 18.32$ \\
\hline Lymphocytes $\left(10^{9} / \mathrm{L}\right)$ & $9.50 \pm 20.72$ \\
\hline Hemoglobin (g/L) & $76.50 \pm 22.49$ \\
\hline Platelet $\left(10^{9} / \mathrm{L}\right)$ & $35.75 \pm 39.30$ \\
\hline Blasts percentage (peripheral blood) & $44.31 \pm 31.85$ \\
\hline Blasts percentage (bone marrow) & $68.11 \pm 20.87$ \\
\hline \multirow[t]{2}{*}{ Cytogenetics } & complex karyotype, $-14,-3,-8$ \\
\hline & $\mathrm{t}(1 ; 11)(\mathrm{p} 22 ; \mathrm{q} 24),+8$ \\
\hline \multirow[t]{2}{*}{ Molecular genetics } & $\begin{array}{l}\text { AML1-ETO, FLT3-ITD, } \\
\text { MLL-AF9, CBFB-MYH11 }\end{array}$ \\
\hline & $\begin{array}{l}\text { NPM1, DNMT3A, CEBPA, TET2, } \\
\text { JAK2, TP53, C-Kit }\end{array}$ \\
\hline
\end{tabular}

Table 5. Relationships between baseline characteristics and gene expression.

\begin{tabular}{|c|c|c|c|c|c|c|}
\hline & & $\begin{array}{c}\text { Age } \\
\text { (younger:older) }\end{array}$ & $\begin{array}{c}\text { Gender } \\
\text { (male:female) }\end{array}$ & WBC & $\begin{array}{c}\text { CD64 } \\
\text { (negative:positive) }\end{array}$ & $\begin{array}{c}\text { CD34 } \\
\text { (negative:positive) }\end{array}$ \\
\hline \multirow[t]{2}{*}{ Bcl-2 } & low & $5: 4$ & $3: 6^{*}$ & $43.48 \pm 65.04$ & $3: 6$ & $3: 6$ \\
\hline & high & $5: 6$ & $10: 1$ & $64.72 \pm 92.73$ & $7: 4$ & $5: 6$ \\
\hline \multirow[t]{2}{*}{ Beclin 1} & low & $5: 5$ & $6: 4$ & $75.34 \pm 98.12$ & $2: 8^{*}$ & $4: 6$ \\
\hline & high & $5: 5$ & $7: 3$ & $34.98 \pm 55.06$ & $8: 2$ & $4: 6$ \\
\hline \multirow[t]{2}{*}{ VPS34 } & low & $6: 4$ & $7: 3$ & $57.00 \pm 87.87$ & $4: 6$ & $4: 6$ \\
\hline & high & $4: 6$ & $6: 4$ & $53.32 \pm 76.38$ & $6: 4$ & $4: 6$ \\
\hline \multirow[t]{2}{*}{ Rubicon } & low & $4: 6$ & $5: 5$ & $71.34 \pm 93.62$ & $2: 8^{*}$ & $4: 6$ \\
\hline & high & $6: 4$ & $8: 2$ & $38.98 \pm 64.93$ & $8: 2$ & $4: 6$ \\
\hline \multirow[t]{2}{*}{ ALFY } & low & $5: 5$ & $9: 1$ & $62.09 \pm 88.53$ & $4: 6$ & $7: 3^{*}$ \\
\hline & high & $5: 5$ & $4: 6$ & $48.23 \pm 74.95$ & $6: 3$ & $1: 9$ \\
\hline \multirow[t]{2}{*}{ UVRAG } & low & $5: 5$ & $6: 4$ & $52.01 \pm 89.88$ & $4: 6$ & $5: 5$ \\
\hline & high & $5: 5$ & $7: 3$ & $58.31 \pm 73.92$ & $6: 4$ & $3: 07$ \\
\hline \multirow[t]{2}{*}{ ULK1 } & low & $6: 4$ & $6: 4$ & $92.72 \pm 98.14 \#$ & $2: 8^{*}$ & 3:07 \\
\hline & high & $4: 6$ & $7: 3$ & $17.60 \pm 28.24$ & $8: 2$ & $5: 5$ \\
\hline \multirow[t]{2}{*}{ NBR1 } & low & $6: 4$ & $6: 4$ & $55.06 \pm 90.91$ & $5: 5$ & $4: 6$ \\
\hline & high & $4: 6$ & $7: 3$ & $55.26 \pm 72.79$ & $5: 5$ & $4: 6$ \\
\hline \multirow[t]{2}{*}{ LC3 } & low & $5: 5$ & $7: 3$ & $77.19 \pm 92.94$ & $3: 7$ & $6: 4$ \\
\hline & high & $5: 5$ & $6: 4$ & $33.13 \pm 62.02$ & $7: 3$ & $2: 8$ \\
\hline \multirow[t]{2}{*}{ p62 } & low & $5: 5$ & $6: 4$ & $44.49 \pm 64.09$ & $5: 5$ & $6: 4$ \\
\hline & high & $5: 5$ & $7: 3$ & $65.83 \pm 95.93$ & $5: 5$ & $2: 8$ \\
\hline
\end{tabular}

*: Fisher's exact test. \#: t-test. 


\section{Beclin 1}

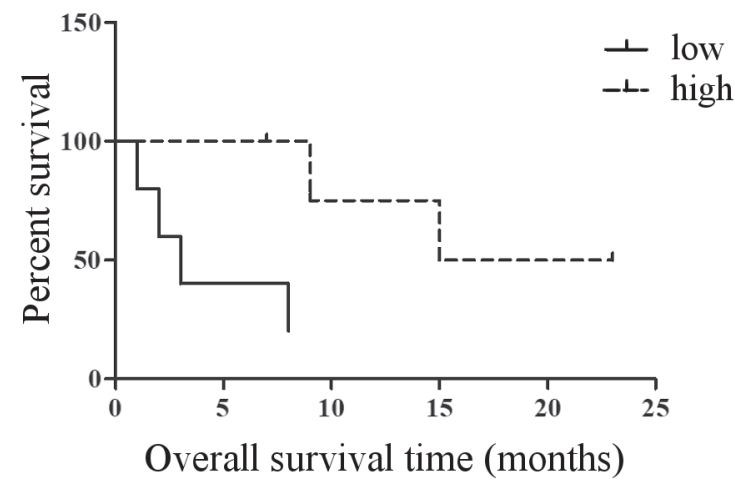

p62

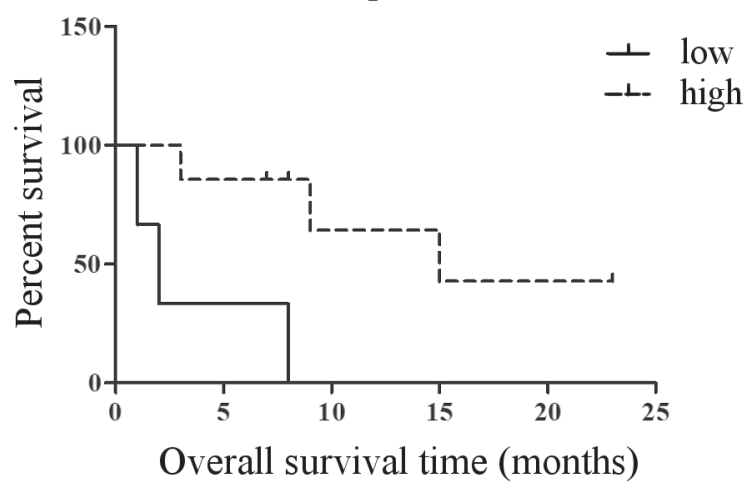

Figure 3. The overall survival of unfavorable patients (OS); Beclin 1 and p62 low expression indicate poor OS

prognosis. Autophagy is a series of protective processes, in which the cell degrades its own macromolecular substances, organelles and cytoplasm under hypoxia, nutritional deficiencies or other metabolic pressures. Under normal conditions, autophagy is inactive because of mTOR activation, but when the internal cellular environment changes, the mTOR pathway is inactivated, and autophagy is initiated by dissociation of the mTOR/ULK1 complex which consists of ULK1/2, ATG13, ATG101 and FIP200 [11]. The Beclin 1/ VPS34 complex can be activated by UVRAG and inhibited by Bcl-2 or Rubicon, while active ULK1 complex activates the Beclin 1/VPS34 complex which is vital to Rubicon and phagophore expansion [12-14].

Phagophore expansion and autophagosome maturation rely on two ubiquitin-like conjugation systems and LC3 forms part of one of these. LC3 is cleaved by ATG4 and transformed to LC3-I and this is then transferred to ATG7 (E1-like enzyme) or ATG3 (E2-like enzyme) and is subsequently conjugated to phosphatidyl ethanolamine to form LC3-II which is an important element of the autophagosome membrane. In the final stage, autophagosomes and lysosomes form autolysosomes which degrade autophagic cargoes by selective degradation [15]. p62 connects ubiquitous proteins and LC3 to achieve selective autophagy[16] and p62 also interacts with the NBR1 and ALFY adaptors of selective autophagy $[17,18]$.

Autophagous processes involve many factors. We therefore examined the expression level of several members of the autophagy network, and results verified that autophagyassociated genes correlate with each other in AML cells (Table 1). Herein, AML patients had lower Beclin 1, LC3, UVRAG, Rubicon and NBR1 expression than normal controls, and more autophagy-associated genes were downregulated in the unfavorable patient group. This is consistent with previous studies which found that the autophagy level is attenuated in AML cells.
Increasing evidence suggests that autophagy is crucial for the generation, development and treatment of AML cells. It has been reported that deletion of FIP200 or ATG7 leads to abnormal differentiation in the hematopoietic system [19] and that chemotherapy drugs such as $\mathrm{As}_{2} \mathrm{O}_{3}$, cytarabine and doxorubicin induce autophagy-related cell death in AML cells [20-22]. Autophagy also promotes the degradation of fusion onco-proteins, including FLT3-ITD, PML-RARA and $\mathrm{BCR}-\mathrm{ABL}$, and thus provides new strategies for leukemia treatment [23-25].

Beclin 1 and LC3 are reportedly down-regulated in AML cells compared to normal cells [26]: with Zare-Abdollahi et al. [8] verifying that Beclin 1 down-regulation is associated with the FLT3-ITD fusion in AML patients. In addition, low ULK1-expression patients had higher WBC counts than the high ULK1 group. CD64 is also considered an immunotherapy target because it is internalized in AML [27], and patients with lower Beclin 1, Rubicon and ULK1 expression had higher positive CD64 rates. Moreover, the low Beclin 1 and p62 expression levels in unfavorable AML patients indicate shorter OS, and our combined results indicate that impaired autophagy facilitates malignant transformation in AML and poor outcomes.

To the best of our knowledge, this is the first research examining the expression of autophagy network regulators in AML patients. Herein, we established the expression levels of autophagy regulators in AML patients and confirmed connections between clinical characteristics and some autophagy-associated genes. The main limitation to this study is the low number of available AML patients, and consequently we had no realistic opportunity to establish the acute myeloid leukemia regulators' protein levels. Further studies are therefore required in this area.

Acknowledgement: This study was funded by the National Natural Science Foundation of China (No.81500135). 


\section{References}

[1] LI YJ, LEI YH, YAO N, WANG CR, HU N et al. Autophagy and multidrug resistance in cancer. Chin J Cancer 2017; 36: 52. https://doi.org/10.1186/s40880-017-0219-2

[2] ZHANG SP, NIU YN, YUAN N, ZHANG AH, CHAO D et al. Role of autophagy in acute myeloid leukemia therapy. Chin J Cancer 2013; 32: 130-135. https://doi.org/10.5732/ cjc. 012.10073

[3] EVANGELISTI C, EVANGELISTI C, CHIARINI F, LONETTI A, BUONTEMPO F et al. Autophagy in acute leukemias: a double-edged sword with important therapeutic implications Biochim Biophys Acta 2015; 1853: 14-26. https://doi. org/10.1016/j.bbamcr.2014.09.023

[4] GIATROMANOLAKI A, SIVRIDIS E, MENDRINOS S, KOUTSOPOULOS AV, KOUKOURAKIS MI et al. Autophagy proteins in prostate cancer: relation with anaerobic metabolism and Gleason score. Urol Oncol 2014; 32: 39.e11-38. https://doi.org/10.1016/j.urolonc.2013.04.003

[5] GIL J, RAMSEY D, SZMIDA E, LESZCZYNSKI P, PAWLOWSKI $\mathrm{P}$ et al. The BAX gene as a candidate for negative autophagy-related genes regulator on mRNA levels in colorectal cancer. Med Oncol 2017; 34: 16. https://doi. org/10.1007/s12032-016-0869-y

[6] ZHOU J, HANG D, JIANG Y, CHEN J, HAN J et al. Evaluation of genetic variants in autophagy pathway genes as prognostic biomarkers for breast cancer. Gene 2017; 627: 549-555. https://doi.org/10.1016/j.gene.2017.06.053

[7] RADWAN SM, HAMDY NM, HEGAB HM, EL-MESALLAMY HO. Beclin-1 and hypoxia-inducible factor-1alpha genes expression: Potential biomarkers in acute leukemia patients. Cancer Biomark 2016; 16: 619-626. https://doi.org/10.3233/ CBM-160603

[8] ZARE-ABDOLLAHI D, SAFARI S, MOVAFAGH A, GHADIANI M, TABARRAEE $M$ et al. Expression analysis of BECN1 in acute myeloid leukemia: association with distinct cytogenetic and molecular abnormalities. Int J Lab Hematol 2016; 38: 125-132. https://doi.org/10.1111/ijlh.12454

[9] MATUTES E, PICKL WF, VAN'T VEER M, MORILLA $\mathrm{R}$, SWANSBURY J et al. Mixed-phenotype acute leukemia: clinical and laboratory features and outcome in 100 patients defined according to the WHO 2008 classification. Blood 2011; 117: 3163-3171. https://doi.org/10.1182/ blood-2010-10-314682

[10] [Chinese guidelines for diagnosis and treatment of adult acute myeloid leukemia (not APL) (2017)]. Zhonghua Xue Ye Xue Za Zhi 2017; 38: 177-182. https://doi.org/10.3760/cm a.j.issn.0253-2727.2017.03.001

[11] ALERS S, LOFFLER AS, WESSELBORG S, STORK B. Role of AMPK-mTOR-Ulk1/2 in the regulation of autophagy: cross talk, shortcuts, and feedbacks. Mol Cell Biol 2012; 32: 2-11. https://doi.org/10.1128/MCB.06159-11

[12] MAIURI MC, CRIOLLO A, TASDEMIR E, VICENCIO JM, TAJEDDINE $\mathrm{N}$ et al. $\mathrm{BH} 3$-only proteins and $\mathrm{BH} 3$ mimetics induce autophagy by competitively disrupting the interaction between Beclin 1 and Bcl-2/Bcl-X(L). Autophagy 2007; 3: $374-376$.
[13] KANG R, ZEH HJ, LOTZE MT, TANG D. The Beclin 1 network regulates autophagy and apoptosis. Cell Death Differ 2011; 18: 571-580. https://doi.org/10.1038/cdd.2010.191

[14] MATSUNAGA K, SAITOH T, TABATA K, OMORI H, SA$\mathrm{TOH} \mathrm{T}$ et al. Two Beclin 1-binding proteins, Atg14L and Rubicon, reciprocally regulate autophagy at different stages. Nat Cell Biol 2009; 11: 385-396. https://doi.org/10.1038/ncb1846

[15] LIPPAI M, LOW P. The role of the selective adaptor p62 and ubiquitin-like proteins in autophagy. Biomed Res Int 2014; 2014: 832704. https://doi.org/10.1155/2014/832704

[16] LIM J, LACHENMAYER ML, WU S, LIU W, KUNDU M et al. Proteotoxic stress induces phosphorylation of p62/ SQSTM1 by ULK1 to regulate selective autophagic clearance of protein aggregates. PLoS Genet 2015; 11: e1004987. https://doi.org/10.1371/journal.pgen.1004987

[17] ISAKSON P, HOLLAND P, SIMONSEN A. The role of ALFY in selective autophagy. Cell Death Differ 2013; 20: 12-20. https://doi.org/10.1038/cdd.2012.66

[18] WALINDA E, MORIMOTO D, SUGASE K, KONUMA T, TOCHIO $\mathrm{H}$ et al. Solution structure of the ubiquitin-associated (UBA) domain of human autophagy receptor NBR1 and its interaction with ubiquitin and polyubiquitin. J Biol Chem 2014; 289: 13890-13902. https://doi.org/10.1074/jbc. M114.555441

[19] MORTENSEN M, WATSON AS, SIMON AK. Lack of autophagy in the hematopoietic system leads to loss of hematopoietic stem cell function and dysregulated myeloid proliferation. Autophagy 2011; 7: 1069-1070.

[20] GOUSSETIS DJ, ALTMAN JK, GLASER H, MCNEER JL, TALLMAN MS et al. Autophagy is a critical mechanism for the induction of the antileukemic effects of arsenic trioxide. J Biol Chem 2010;285: 29989-29997. https://doi.org/10.1074/ jbc.M109.090530

[21] RISTIC B, BOSNJAK M, ARSIKIN K, MIRCIC A, SUZINZIVKOVIC $\mathrm{V}$ et al. Idarubicin induces mTOR-dependent cytotoxic autophagy in leukemic cells. Exp Cell Res 2014; 326: 90-102. https://doi.org/10.1016/j.yexcr.2014.05.021

[22] FERNANDES A, AZEVEDO MM, PEREIRA O, SAMPAIOMARQUES B, PAIVA A et al. Proteolytic systems and AMPactivated protein kinase are critical targets of acute myeloid leukemia therapeutic approaches. Oncotarget 2015; 6: 31428-31440. https://doi.org/10.18632/oncotarget.2947

[23] LARRUE C, SALAND E, BOUTZEN H, VERGEZ F, DAVID $\mathrm{M}$ et al. Proteasome inhibitors induce FLT3-ITD degradation through autophagy in AML cells. Blood 2016; 127: 882892. https://doi.org/10.1182/blood-2015-05-646497

[24] ZENG CW, CHEN ZH, ZHANG XJ, HAN BW, LIN KY et al. MIR125B1 represses the degradation of the PML-RARA oncoprotein by an autophagy-lysosomal pathway in acute promyelocytic leukemia. Autophagy 2014; 10: 1726-1737. https://doi.org/10.4161/auto.29592

[25] COLECCHIA D, ROSSI M, SASDELLI F, SANZONE S, STRAMBI A et al. MAPK15 mediates BCR-ABL1-induced autophagy and regulates oncogene-dependent cell proliferation and tumor formation. Autophagy 2015; 11: 1790-1802. https://doi.org/10.1080/15548627.2015.1084454 
[26] WATSON AS, RIFFELMACHER T, STRANKS A, WILLIAMS O, DE BOER J et al. Autophagy limits proliferation and glycolytic metabolism in acute myeloid leukemia. Cell Death Ciscov 2015; 1.
[27] Stahnke B, Thepen T, Stocker M, et al. Granzyme B$\mathrm{H} 22(\mathrm{scFv})$, a human immunotoxin targeting CD64 in acute myeloid leukemia of monocytic subtypes. Mol Cancer Ther 2008; 7: 2924-2932. https://doi.org/10.1158/1535-7163. MCT-08-0554 